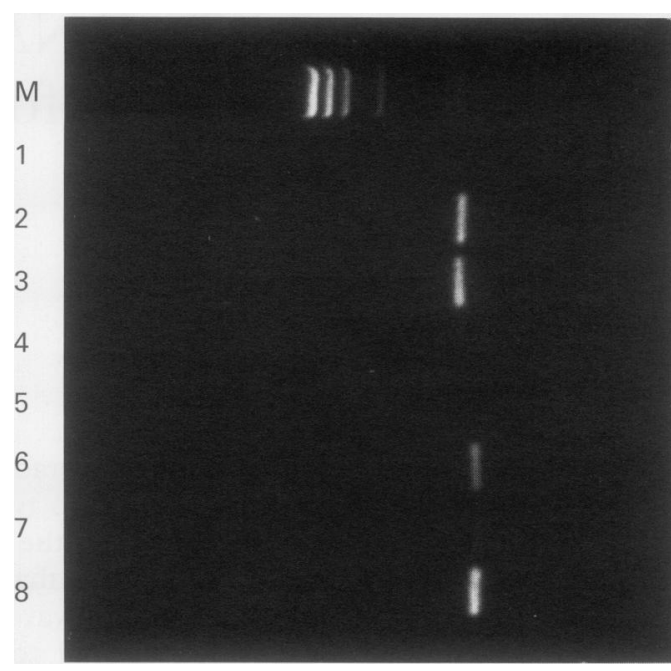

Figure 1 Agarose gel (2.5\%) electrophoresis of PCR products generated from $D N A$ isolated from paraffin wax embedded liver (lanes 1-4) and brain (lanes 5-8) tissue. Lane $M, \Phi \times 174$ DNA markers; lanes 1 and 5, blank controls (no DNA added); lanes 2-4, 237 bp AAT gene fragment amplified from liver tissue; lanes 6-8, $227 \mathrm{bp}$ APOE gene fragment amplified from brain tissue.

Using the method describe herein, it is possible to obtain amplification products reproducibly from DNA isolated from paraffin wax embedded liver and brain tissue. PCR products up to around $240 \mathrm{bp}$ in size can be generated consistently, which in the majority of cases permits further genetic analysis to be performed. We used the $227 \mathrm{bp}$ APOE PCR prod- uct that was amplified from five paraffin wax embedded brain tissue samples for genotyping ${ }^{6}$ and the results obtained matched those determined previously using DNA prepared from frozen $\left(-20^{\circ} \mathrm{C}\right)$ brain tissue, that had been in storage following necropsy, in all five cases (data not shown). As this method is so simple and rapid, it should now be possible to analyse large numbers of preserved samples at the molecular level.

We are very grateful to Nicola Buckley and Roy Edward from Dynal (UK) Ltd for the gift of the Dynabeads DNA DIRECT kit. This work was supported by grants from the Wellcome Trust and Nottingham University Hospitals Trustees.

1 Impraim CC, Saiki RK, Erlich HA, Teplitz RL. Analysis of DNA from formalin-fixed, paraffin embedded tissues by enzymatic amplification and hybridization with sequencespecific oligonucleotides. Biochem Biophys Res Commun specific oligonucleot

2 Shibata DK, Arnheim N, Martin WJ. Detection of human papilloma virus in paraffin-embedded tissue using the polymerase chain reaction. $\mathcal{F} \operatorname{Exp} M e d$ 1988;167:225-30.

3 Wright DK, Manos MM. In: Innis MA, Gelfand DH, Sninsky JJ, WhiteTJ, eds. PCR protocols: a guide to methods and applications. London: Academic Press, 1990:153-8.

4 Chen BF, Clejan S. Rapid preparation of tissue DNA from paraffin-embedded blocks and analysis by polymerase chain reaction. F Histochem Cytochem 1993;41:765-8.

5 Banerjee SK, Makdisi WF, Weston AP, Mitchell SM, Campbell DR. Microwave based DNA extraction from paraffinembedded tissue from PCR amplification. Biotechniques embedded tissue

6 Wenham PR, Price WH, Blandell G. Apolipoprotein E genotyping by one stage PCR (letter). Lancet 1991; 337:1 158-9.

7 Newton CR, Kalsheker N, Graham A, Powell S, Gammack A, Riley J, Markham A. Diagnosis of alpha-1-antitrypsin deficiency by enzymatic amplification of human genomic DNA and direct sequencing of polymerase chain reaction products. Nucleic Acids Res 1988;16:8233-43.
Molecular

Haematology Unit, Department of Haematology, Bristol Royal Infirmary, Bristol BS2 8HW J S Webb G R Standen

Department of Histopathology C M P Collins C P Case

Correspondence to: Dr G R Standen.

\title{
Postmortem diagnosis of Factor V Leiden from paraffin wax embedded tissue
}

\author{
J S Webb, G R Standen, C M P Collins, C P Case
}

\begin{abstract}
Activated protein $\mathrm{C}$ resistance resulting from Factor $V$ Leiden is an important inherited thrombophilia disorder which is found in $3.5 \%$ of people in the UK. The genetic defect can be detected using the PCR and the diagnosis can be made postmortem from paraffin wax embedded tissue. The presence of Factor $V$ Leiden should be sought in all cases of unexplained sudden death resulting from venous thromboembolism.
\end{abstract}

(f Clin Pathol: Mol Pathol 1996;49:M180-M181)

Keywords: Factor V Leiden, thromboembolism, thrombophilia disorder.

Activated protein $\mathrm{C}$ resistance has been recognised recently as an important risk factor predisposing to venous thromboembolism. ${ }^{1}$ The disorder results from a specific missense mutation (G1691A) in exon 10 of the coagula- tion factor $\mathrm{V}$ gene, which is located in the sequence encoding the activated protein $\mathrm{C}$ cleavage site. ${ }^{2}$ Recent studies have shown that the mutant factor Va (Factor V Leiden) is 10 times less susceptible to deactivation by this natural anticoagulant. ${ }^{3}$ Factor V Leiden can be detected by means of the PCR as the nucleotide base change eliminates a cleavage site for the restriction enzyme, Mnll. ${ }^{2} \mathrm{Re}-$ cently, we have demonstrated the importance of diagnosing this disorder retrospectively from postmortem paraffin wax embedded tissue.

\section{Case report}

A 24 year old man sustained a soft tissue laceration to the right leg following a road traffic accident. The wound was debrided and sutured and the patient was prescribed diclofenac sodium (Voltarol) as analgesia. One week later, he presented with lower abdominal pain and appendicitis was diagnosed provision- 


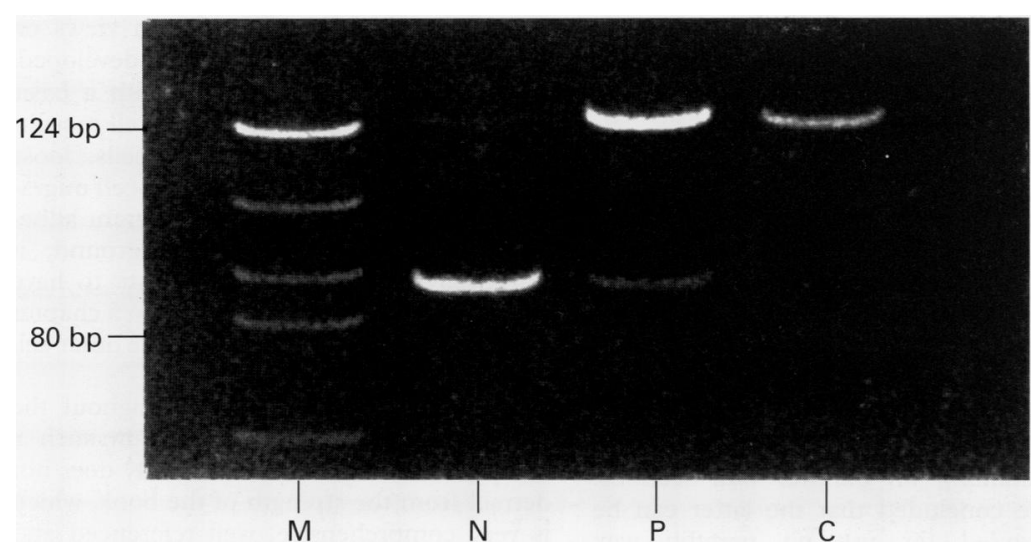

Figure 1 Detection of FactorV Leiden by PCR: amplified 147 bp fragment digested with Mnl1 for a normal subject $(N)$, patient $P$ who is heterozygous for the mutation and a homozygous control $(C) . M=$ molecular size markers ( $P B R 322$ digested with HaeIII).

ally. Laparotomy was performed and revealed a short section of thickened distal ileum. This was resected without complication, but two days after the procedure the patient developed dyspnoea and subsequently collapsed and suffered a cardiac arrest. Postmortem examination revealed massive pulmonary embolus. Histology of the distal ileum showed typical Diaphragm disease as described in association with use of non-steroidal anti-inflammatory drugs. ${ }^{4}$

POLYMERASE CHAIN REACTION

To detect Factor V Leiden, several $15 \mu \mathrm{m}$ sections of paraffin wax embedded myocardial tissue were placed in a $0.5 \mathrm{ml}$ Eppendorf tube and $100 \mu \mathrm{l}$ sterile water was added together with $100 \mu$ l proteinase $\mathrm{K}$ buffer solution $(25 \mu \mathrm{l}$ $5 \%$ Tween, $250 \mu \mathrm{l} 20 \mathrm{mg} / \mathrm{ml}$ proteinase $\mathrm{K}, 100$ $\mu 1 \mathrm{M}$ Tris $\mathrm{HCl}$ (pH 8.3), and sterile water to $500 \mu \mathrm{l})$. The solution was covered with $100 \mu \mathrm{l}$ mineral oil and incubated at $55^{\circ} \mathrm{C}$ for 42 hours before boiling for 10 minutes at $100^{\circ} \mathrm{C}$ and microcentrifugation. Ten microlitres of the supernatant was used for each PCR. The oligoprimers and PCR conditions described by Beauchamp et $a l^{5}$ were used to detect the mutation.

An aliquot of the product was incubated with two units of the restriction enzyme Mnll for three hours at $37^{\circ} \mathrm{C}$ prior to electrophoresis on an $8 \%$ polyacrylamide gel and staining with ethidium bromide. Two restriction sites for this enzyme are present in normal subjects, giving fragments of 85,37 and 25 base pairs (bp). The Leiden mutation eliminates one of these sites, however, and bands of 122 and $25 \mathrm{bp}$ are obtained. Patient $\mathrm{P}$ was confirmed to be heterozygous for this defect (fig 1).

\section{Discussion}

Heterozygous Factor V Leiden is found in $3.5 \%$ of the population of the UK. ${ }^{5}$ It can be identified in about $20 \%$ of subjects with de novo venous thrombosis and accounts for about $40 \%$ of familial thrombophilia. ${ }^{6}$ The genetic defect is an important cofactor for thromboembolism associated with use of oral contraceptives ${ }^{7}$ and pregnancy. ${ }^{8}$ Homozygous subjects and those patients who co-inherit a second thrombophilia disorder are probably at significantly higher risk. ${ }^{9} 10$

Postmortem detection of Factor V Leiden from fresh or paraffin wax embedded tissue should be considered in all cases of unexplained sudden death where venous thromboembolism is suspected. Any tissue containing nucleated cells can be used as a source of DNA-for example, liver or lung tissue obtained by a "tru-cut" biopsy. Retrospective diagnosis enables family studies and genetic counselling to be performed. The technique may also allow important studies to be undertaken on archival material-for example, to determine the significance of Factor $\mathrm{V}$ Leiden as a risk factor for maternal death resulting from thromboembolism in pregnancy.

1 Dahlback B, Carlsson M, Svensson PJ. Familial thrombophilia due to a previously unrecognized mechanism characterized by poor anticoagulant response to activated protein C. Proc Natl Acad Sci USA 1993;90:1004-8.

2 Bertina RM, Koeleman BPC, Koster T, Rosendaal FR, Dirven RJ, de Ronde $\mathrm{H}$, et al. Mutation in blood coagulation factor $\mathrm{V}$ associated with resistance to activated protein C. Nature 1994;369:64-7.

3 Heeb MJ, KojimaY, Greegard JS, Griffin JH. Activated protein $C$ resistance: molecular mechanisms based on studie using purified Gln $\ln ^{506}$ - factor V. Blood 1995;85:3405-11.

4 Lang J, Price AB, Levi AJ, Burke M, Gumpel JM, Bjarnason I. Diaphragm disease; pathology of the small intestine induced by non-steroidal anti-inflammatory drugs. $₹$ Clin Pathol 1988;41:516-26.

5 Beauchamp NJ, Daly ME, Hampton KK, Cooper PC, Preston FE, Peake IR. High prevalence of a mutation in the factor $\mathrm{V}$ gene within the U.K. population: relationship to activated protein $C$ resistance and familial thrombosis. $B$ f Haematol 1994;88:219-22.

6 Dahlback B. Inherited thrombophilia: resistance to activated protein $C$ as a pathogenic factor for venous thromboembolism. Blood 1995;85:607-14.

7 Vandenbroucke JP, Koster T, Briet E, Reitsma RH, Bertina RM, Rosendaal FR. Increased risk of venous thrombosis in oral contraceptive users who are carriers of factor $V$ Leiden mutation. Lancet 1994;344:1453-7.

8 De Stefano V, Mastrangelo S, Paciaroni K, Ireland H, Lane DA, Scirpa $\mathrm{P}$, et al. Thrombotic risk during pregnancy and puerperium in women with APC-resistance: effective subcutaneous heparin prophylaxis in a pregnant patient (letter). Thromb Haemost 1995;74:793-4.

9 Rosendaal FR, Koster T, Vandenbroucke JP, Reitsma BH. High risk of thrombosis in patients hcmozygous for factor $\mathrm{V}$ Leiden (activated protein C resistance). Blood 1995; 85:1504-8.

10 Koeleman BPC, Van Rumpt D, Hamulyak K, Reitsma PH, Bertina RM. Factor V Leiden: an additional risk factor for thrombosis in protein $S$ deficient families? Throm Haemost 1995;74:580-3. 